\title{
AN INTERSTATE CIRCUIT APPROACH TO THE REFUSAL TO DEAL DILEMMA UNDER SECTION 3 OF THE CLAYTON ACT *
}

Manufacturers often desire to market their products through exclusive dealerships. ${ }^{1}$ Under such an arrangement, the manufacturer is able to demand loyalty from his sales outlets, to lower sales costs, and to provide efficient servicing for the consumer. ${ }^{2}$ However, a network of these dealerships restricts competition on two levels of enterprise: competing manufacturers are foreclosed from the use of desirable outlets, and dealers are denied the freedom to handle the products of other manufacturers. ${ }^{3}$ Moreover, if the dealership is granted in conjunction with an exclusive territorial agency, ${ }^{4}$ competing outlets within the exclusive area are denied access to the manufacturer's product, and retail price competition within the industry may be severely restricted. ${ }^{5}$

The threat to competition inherent in the use of exclusive dealer contracts led Congress to enact Section 3 of the Clayton Act which prohibits such

*Leo J. Meyberg Co. v. Eureka Williams Corp., 215 F.2d 100 (9th Cir.), ccrt. denied, 75 S. Ct. 113 (1954); Nelson Radio \& Supply Co. v. Mlotorola, Inc., 200 F.2d 911 (5th Cir. 1952), cert. denied, 345 U.S. 925 (1953).

1. "An exclusive dealership arrangement ... is one in which a supplier secures exclusive marketing outlets by arranging with dealers to handle its products to the exclusion of all competing products ... ." Lockhart \& Sacks, The Relezonce of Economic Factors in Determining Whether Exclusive Arrangements I'iolate Section 3 of the Claytor Act, 65 HARv. I. REv. 913, 914 (1952). This may take the form of a requirements contract, in which the supplier agrees to sell the buyer, and the buyer agrees to purchase, all of the buyer's requirements of a product for a certain length of time. Ibid.

2. An intensive sales effort is often required for the distribution of mechanical and electrical equipment. Relatively detailed demonstration and installation may be necessary, and special maintenance services are frequently required. Consequently, the exclusive dealership may be essential to effective distribution of the manufacturer's goods. WaTkI: Public Regulation of Cosipetitive Practices 210-11 (1940). Aloreover, its purpose may be simply to reduce sales cost, or to insure maximum sales effort by dealers. Lochihart \& Sacks, supra note 1 , at $921-22$.

3. For the factors determining the effects on competition of such arrangements, see Lockhart \& Sacks, supra note 1, at 923-29.

4. An exclusive sales agency, by which a buyer obtains exclusive distribution rights in a designated territory, is often very effective in eliminating competition at the buyer', market level. However, these sales arrangements have been generally upheld. See Comment, Refisals to Sell and Public Control of Competition, 58 YALE L.J. 1121, 1130-32 (1949).

5. Exclusive dealerships make access to the consumer market more difficult for the new or small manufacturers who are the most common price cutters. A dealer handling a well-known brand is less likely to use price cutting as a means of competing with other dealers. This is especially true where he receives an exclusive agency. See Dirusus \& KaHN, Fair Cospetition 199-201 (1954). 
contracts whenever their effect may be substantially to lessen competition. ${ }^{0}$ In the leading case of Standard Oil Co. of California $v$. United States, ${ }^{7}$ the Supreme Court condemned the employment of this device by the largest seller in the industry ${ }^{8}$ and apparently held that exclusive dealer contracts affecting a substantial amount of business are illegal per se when utilized by a seller who is a major factor in his market. ${ }^{9}$ Recent cases have re-emphasized that these arrangements are unlawful whenever there is a reasonable probability of substantial injury to competition. ${ }^{10}$

In United States $v$. Colgate, ${ }^{11}$ however, the Supreme Court held that a manufacturer has the right to refuse to sell to anyone for any reason. The scope of this rule has been severely limited in subsequent cases. A manufacturer cannot refuse to sell if its design is to create or maintain a monopoly. ${ }^{12}$ Nor can a manufacturer go beyond a mere refusal to sell and receive cooperation from its dealers in reporting nonconformists. ${ }^{13}$ But the Colgate doctrine

6. "It shall be unlawful for any person engaged in commerce, in the course of such commerce, to lease or make a sale or contract for sale of goods, wares, merchandise, machinery, supplies or other commodities, ... on the condition, agreement or understanding that the lessee or purchaser thereof shall not use or deal in the goods, wares, merchandise, machinery, supplies, or other commodities of a competitor or competitors of the lessor or seller, where the effect . . . may be to substantially lessen competition or tend to create a monopoly in any line of commerce." 38 STAT. 731 (1914), 15 U.S.C. $\S 14$ (1952).

7. 337 U.S. 293 (1949).

8. Standard Oil Co. of California v. United States, 337 U.S. 293, 295 (1949).

9. Id. at 314. See United States v. Richfield Oil Corp., 99 F. Supp. 280 (S.D. Cal. 1951), aff'd per curiam, 343 U.S. 922 (1952) ; Transamerica Corp. v. Board of Governors of Federal Reserve System, 206 F.2d 163, 170 (3d Cir. 1953) (dictun).

10. E.g., Dictograph Products, Inc. v. FTC, 2 d Cir., Dec. 15, 1954. See also HarleyDavidson Motor Co., CCH Trade Reg. Rep. (1954 Trade Cas.) If 25,108 (FTC 1954); Revion Products Corp., CCH Trade Reg. Rep. (1954 Trade Cas.) $\llbracket 25,184$ (FTC 1954).

11. 250 U.S. 300 (1919). Defendant distributed circulars and letters urging its dealers to adhere to uniform prices and stating that no sales would be made to those who did not. Defendant uniformly refused to sell to offenders. Dismissing the indietment, the court broadly affirmed the right to cease dealing with anyone. Furthermore, the court stated that an individual may state in advance the circumstances under which he will refuse to sell.

12. Lorain Journal v. United States, $3+2$ U.S. 143 (1951) (refusal of newspaper to sell advertising space to radio advertisers held an attempt to monopolize); Eastman Kodak Co. v. Southern Photo Materials Co., 273 U.S. 359 (1927) (refusal to sell to wholesaler held an attempt to monopolize film distribution); United States v. Klearflax Linen Looms, Inc., 63 F. Supp. 32 (D. Minn. 1945) (refusal to deliver rugs to distributor who had underbid defendant on a government contract held an attempt to monopolize). See Comment, 58 YALE L.J. 1121, 1134-36 (1949).

13. In FTC v. Beech-Nut Packing Co., 257 U.S. 441 (1922), the Court condemned defendant's distribution system and attempted to distinguish Colgate because of the methods Beech-Nut adopted to make its refusal to deal effective. However, there secms to be very little difference between the two plans. Several lower court decisions lave subsequently applied Beech-Nut. Hills Bros. v. FTC, 9 F.2d 481 (9th Cir.), ccrt. denicd, 270 U.S. 662 (1926); Q.R.S. Music Co. v. FTC, 12 F.2d 730 (7th Cir. 1926); Toletto Pipe-Threading Machine Co. v. FTC, 11 F.2d 337 (6th Cir. 1926). Professor Chaffec has 
is still frequently cited and applied. ${ }^{14}$ And two recent decisions 15 indicate that if a manufacturer establishes exclusive outlets by refusing to sell to dealers handling competing products it can have such arrangements upheld, although the effect on competition may be the same as that of exclusive dealer contracts. Furthermore, even if exclusive dealer contracts are used, a private party denied a franchise because he refuses to deal exclusively may be unable to sue for treble damages. ${ }^{16}$

In Nelson Radio \& Supply Co. v. Motorola, Inc., ${ }^{17}$ the Fifth Circuit applied the Colgate doctrine and dismissed the complaint for failure to state a cause of action under the antitrust laws. Plaintiff was a distributor of Motorola's radio, television, and communication equipment for several years prior to 1949. In that year Motorola informed it that it would no longer be allowed to distribute Motorola communication equipment and that its franchise to sell Motorola radio and television receivers would not be renewed unless plaintiff agreed not to distribute communication equipment manufactured by firms in competition with Motor-

stated that the Beech-Nut line of cases proscribes almost all effective methods of excrcising the right upheld in Colgate. Equitable Servitudes on Chattels, 41 Hasv. L Rxw. 945, 991 (1927). For similar views on the encroachments on Colgate, see Judge Frank's dissenting opinion in Adams-MFitchell Co. v. Cambridge Distributing Co., 189 F.2d 913, 924 (1951) ; Comment, 58 YaLe L.J. 1121, 1127-29 (1949); Timberg, Selection of Cistamers in How to Complyy with the ANtitrust Laws 117 (Van Cise \& Dunn ed. 1954).

The courts have almost consistently condemned refusals to sell which are the result of group action. Comment, 58 Yale L.J. 1121, 1136-40 (1949). The leading modern case on group boycott is Fashion Originators' Guild of America v. IFTC, 312 U.S. 457 (1941). A combination in the women's garment industry refused to sell to manufacturers and retailers who dealt in designs copied from their members. The Supreme Court held that the Federal Trade Commission was not in error in refusing to hear the evidence which the combination offered to justify its action. See also Associated Press v. United States, 326 U.S. 1 (1945); United States v. Columbia Steel Co., 334 U.S. 495, 522 (1948) (dictum).

14. See Brosious v. Pepsi-Cola Co., 155 F.2d 99 (3d Cir. 1945) (soit drink bottler refused to supply plaintiff unless plaintiff agreed to handle only Pepsi); Johnson v. J. H. Yost Lumber Co., 117 F.2d 53 (8th Cir. 1941) (suppliers refused to sell to cut-rate lumber dealer); Camfield IIfg. Co. v. MicGraw Electric Co., 70 F. Supp. 477 (D. Del. 1947) (refusal to sell "Toastmaster" to distributors selling plaintiff's toaster).

In Adams-3ritchell Co. v. Cambridge Distributing Co., 189 F.2d 913 (2d Cir. 1951), the Second Circuit applied Colgate although there was a contract betwreen the distributor and plaintiff in which the distributor agreed to control the wholesale price of a certain whisky. The distributor evidently planned to refuse to sell to other wholesalers not maintaining the suggested price, and the court declared that the distributor had the right to do so under Colgate. However, the court's statement was mere dictum because it held that the price maintenance plan was exempt from the Sherman Act by virtue of the Miller-Tydings Amendment. Id. at 916.

15. Leo J. Meyberg Co. v. Eureka Williams Corp., 215 F.2d 100 (9th Cir.), ecrt. denied, 75 S. Ct. 113 (1954); Nelson Radio \& Supply Co. v. MIotorola, Inc., 200 F.2d 911 (5th Cir. 1952), cert. denied, 345 U.S. 925 (1953).

16. Ibid. See text at notes 17-19.

17. 200 F.2d 911 (5th Cir. 1952), cort. deried, 345 Li.S. 925 (1953). 
ola. Plaintiff rejected these conditions and sued Motorola to recover treble damages for injury to its business resulting from the termination of its distributor contract. The court held that Motorola's refusal to continue business relations with plaintiff except on the specified conditions was merely a refusal to deal which was permissible under Colgate. ${ }^{18}$ There was no exclusive dealer contract subject to attack under the Clayton Act because there was no contract at all; the previous contract between the parties had terminated, and no new one had been entered into. Contracts with distributors in other areas which prevented them from dealing with competitors of Motorola were held not to have injured plaintiff and therefore they provided no ground for complaint on its part. ${ }^{10}$ Thus, although Motorola employed exclusive dealer contracts whenever it could persuade or coerce distributors to make them, ${ }^{20}$ plaintiff was unable to recover simply because it made the mistake of suing before submitting to defendant's demands. Presumably, if it had merely signed the contract which Motorola had urged on it, plaintiff could then have recovered for the injury to its business resulting from that contract. ${ }^{21}$

In Leo J. Meyberg Co. v. Eureka Williams Corp.,22 the Ninth Circuit also dismissed a distributor's complaint, holding that the refusal of a manufacturer to continue dealing with plaintiff because plaintiff insisted on handling a competing line did not violate the Clayton Act. Plaintiff argued that since Section 3 of the Clayton Act prohibits certain exclusive dealer contracts, it was also a violation of the Act to cancel a franchise for refusal to agree to or abide by such an arrangement. ${ }^{23}$ The court cited no decisions, but, following the line of reasoning employed in $\mathrm{Nelson}$, concluded that neither a private nor a government action would be successful in such a situation. ${ }^{24}$

These two cases demonstrate one of the wealnnesses of the antitrust laws: by merely prohibiting the contracts, combinations, and conspiracies by which unreasonable effects on competition are engendered rather than the tunreasonable effects themselves, the laws are often unable to deal effectively with uni-

18. Nelson Radio \& Supply Co. v. Motorola, Inc., 200 F.2d 911, 915-16 (5th Cir. 1952).

19. Id. at 915 .

20. Id. at 913 .

21. "There is a real difference between the act of refusing to deal and the exceution of a contract which prevents a person from dealing with another." Id. at 916. 'The Court assumed that Motorola's contracts with other distributors violated $\S 3$ of the Clayton Act and gave no reason for denying recovery other than that no such contract existed between plaintiff and Motorola. Id. at 915. But cf. Hudson Sales Corp. v. Waldrip, 211 F.2d 268 (5th Cir. 1954).

22. 215 F.2d 100 (9th Cir.), cert. denied, 75 S. Ct. 113 (1954).

23. Opening Brief for Appellant, p. 4, Leo J. Meyberg Co. v. Eureka Williams Corp., 215 F.2d 100 (9th Cir. 1954).

24. The record in Meyberg gives no information of contracts with other dealers such as existed in Nelson. Thus, the government may not have the basis for a stuccessful action against Eureka Williams under the Clayton Act, as it probably had against IIotorola. See 53 Colum. L. Rev. 874, 876 (1953). 
lateral action by firms which have substantial but not monopoly power. ${ }^{25}$ However, sophisticated courts have pierced through form to substance and manipulated the doctrines of combination and conspiracy when necessary to effectuate the public policy in favor of competition. ${ }^{20}$ One of the leading cases in this trend is Interstate Circuit, Inc. v. United States. ${ }^{27}$ Interstate, a motion picture exhibitor with substantial market power, wrote a form letter to various distributors, demanding as a condition of its continued exhibition of their films that the distributors impose certain arbitrary restrictions on the exhibition of films by Interstate's competitors. ${ }^{28}$ Each distributor agreed to follow Interstate's demands. The Supreme Court held that an express agreement was not a prerequisite to an unlawful conspiracy among the distributors. ${ }^{20}$ It pointed out that an unlawful conspiracy is often formed without simultaneous action or agreement by the conspirators, ${ }^{30}$ and held that it was sufficient that the distributors adhered to Interstate's scheme knowing that concerted action was planned and invited, and that such action would result in restraint of trade..$^{31}$ Thus, under the Sherman Act, ${ }^{32}$ a known plan and an invitation (or coercion) to participate can provide the link between individual conspirators, taking the place of a formal agreement. ${ }^{33}$

25. Handler, A Study of the Construction and Enforcejent of the Federul ANTItrust Laws 43 (TNEC Monograph No. 38, 1941).

26. The doctrine of "conscious parallel action" has been developed by the courts to strike down certain practices in the oligopolistic industries. This involves the inferring of a "conspiracy" from apparently independent acts. The principle is not new. Cf. Eastern States Lumber Ass'n v. United States, 234 U.S. 600, 612 (1914). However, it has been greatly expanded in recent years. See American Tobacco Co. v. United States, 323 U.S. 781 (1946) ; FTC v. Cement Institute, 333 U.S. 683 (1948). For the brosdest application of the doctrine, see Milgram v. Loew's, Inc, 192 F.2d 579 (3d Cir. 1951), cert. denicd, 343 U.S. 929 (1952). But cf. Theatre Enterprise, Inc. v. Paramount Film Distributing Corp., 346 U.S. 537 (1954).

The courts have also found conspiracy between a parent corporation and its subsidiaries, thus prohibiting many corporate activities formerly thought immune from the Sherman Act. See United States v. General Motors Corp., 121 F.2d 376 (7th Cir.), cert. denied, 314 U.S. 618 (1941); Schine Chain Theaters v. United States, 334 U.S. 110 (1948); United States v. New York Great Atlantic \& Pacific Tea Co., 173 F.2d 79 (7th Cir. 1949). For a complete study of the doctrine of intra-enterprise conspiracy, sec Comment, 63 Y AXE L.J. 372 (1954).

In general, see United States v. American Tobacco Co., 221 U.S. 106, 180-81 (1911); United States v. MIasonite Corp., 316 U.S. 265, 276-80 (1942); Timken Roller Bearing Co. v. United States, 341 U.S. 593, 597-600 (1951).

27. 306 U.S. 208 (1939).

28. Interstate Circuit, Inc. v. United States, 306 U.S. 208, 215-18, 230-31 (1939).

29. Id. at 226.

30. See United States v. Masonite Corp., 316 U.S. 265, 275 (1942); United States v. General Motors Corp., 121 F.2d 376, 408 (7th Cir. 1941); Jarino v. United States, 91 F.2d 691, 696 (9th Cir. 1937); MrcDonald v. United States, 89 F.2d 128, 133 (8th Cir. 1937).

31. Interstate Circuit, Inc. v. United States, 306 U.S. 203, 220 (1939).

32. 26 STAT. 209 (1890), 15 U.S.C. \& 1 (1952).

33. Interstate Circuit, Inc. v. United States, 306 U.S. 208, 227 (1939). 
Interstate provides an effective method of attacking many refusal-to-deal situations. $^{34}$ The manufacturer and his exclusive dealers can be charged with participating in a nation-wide conspiracy to restrain trade in their industry by constricting the market opportunities of competing producers and narrowing the sources from which competing distributors can buy. When the manufacturer informs his distributors that he will no longer sell to anyone who also distributes the goods of competing producers, he is inviting (or attempting to coerce) them to agree to boycott competing producers ${ }^{36}$ in return for his promise to refuse to sell to any dealer who is unwilling to cooperate.17

34. Of course, in many cases, this use of the Interstate formula would not be sufficient. There will be instances where the refusal to deal is only an isolated busincss practice. generally because of a decline in sales of the manufacturer's product. In other situations, the trier of fact might find that the dealer did not join in the common plan but exercised its own independent business judgment. Cf. Theatre Enterprises, Inc. v. Paramount Film Distributing Corp., 346 U.S. 537 (1954) ; Johnson v. J. H. Yost Lumber Co., 117 F.2d 53 (8th Cir. 1941) ; Brosious v. Pepsi-Cola Co., 155 F.2d 99 (3d Cir. 1946). Sec' alsn United States v. Bausch \& Lomb Optical Co., 321 U.S. 707, 713-16, 723, 719 (1944), affirming 45 F. Supp. 387, 397, 396 (S.D.N.Y. 1942). As a third stumbling block, the court might find that the agreement does not unreasonably restrict competition. Cf. Hiulson Sales Corp. v. Waldrip, 211 F.2d 268 (5th Cir. 1954).

35. In Fashion Originators' Guild, Inc. v. FTC, 312 U.S. 457, 465 (1941), the Supreme Court, in discussing the Guild's exclusive dealer plan of not selling to retailers who handled copied garments, stated: "[I]t narrows the outlets to which garment and textile manufacturers can sell and the sources from which retailers can buy."

The conspiracy need not be "nation-wide." Conspirators may be convicted of restraining any part of interstate commerce which can be regarded as an economic market. Indiauna Farmer's Guide Publishing Co. v. Prairie Farmer Publishing Co., 293 U.S. 268, 279 (1934) ; United States v. Yellow Cab Co., 332 U.S. 218, 225-26 (1947); Standard Oil Co. of California v. United States, 337 U.S. 293, 299-300 (1949).

36. "Here we have in fact an agreement among the wholesalers through Soft-Lito and an agreement among the retailers through Soft-Lite. . . Each participant, of course, understands that he is of a larger system. . . . Defendants call the favored retailers 'licensees.' When admitted to the privilege of purchasing Soft-Lite lenses they received from Soft-Lite a document called a license. But Soft-Lite has no privilege to confer. The right to buy Soft-Lites from those who own them is not within its gift. . . . Without the boycott maintained by it, in concert with the wholesalers, against unlicensed retailers, Soft-Lite's attempt to exercise this pretended power would have been a mere theatrical gesture. The force which transferred the license from the stage to the market place was the force of the boycott. And it is this very exertion of force by agreement or combination against the freedom of trade which is outlawed by the Sherman Act." United States v. Bausch \& Lomb Optical Co., 45 F. Supp. 387, 397, 396 (S.D.N.Y. 1942), aff'd, 321 U.S. 707, 723 (1944).

The right to select one's suppliers is just as fundamental as the right to select onc's customers. In Interstate a conspiracy was found when an exhibitor (retailer) refused to deal with distributors (manufacturer-wholesalers) except on condition that the distributors (manufacturer-wholesalers) restrict their dealings with competitors of the eslibitor (competing retailers). Similarly a conspiracy may be found when a manufacturer reftses to deal with retailers except on condition that the retailers restrict their dealings with competitors of the manufacturer.

37. The consideration for the dealer's agreement to handle exclusively the manufacturer's product will vary. In some cases the manufacturer will agree to sell only through exclusive dealers. In others he will merely agree to supply his product to the 
Any dealer who then handles only the manufacturer's line knowingly participates in the plan and thus joins the conspiracy. ${ }^{38}$ Mere acquiescence in the scheme is just as illegal as initiation of the plan. ${ }^{39}$ And economic coercion is no defense to a charge of conspiracy to violate the antitrust laws. ${ }^{40}$ Even plaintiff's prior participation in the conspiracy will seldom prevent recovery from the manufacturer and cooperating distributors. ${ }^{21}$

dealer. And in others he may grant the dealer the right to distribute his product exclusively in a certain area. See Lockhart \& Sacks, The Relezance of Economic Factors in Determining Whether Exclusive Arrangements Violate Section 3 of the Clayton Act, 65 HARv. L. REv. 913, 920-21 (1952). The effect of the arrangement on competition, and therefore its legality, will vary with the consideration for the dealer's agreement. Id. at 923-29.

38. "That is true though the District Court found that in negotiating and entering into the first agreements each appellee, other than Masonite, acted independently of the others, negotiated only with Masonite, desired the agreement regardless of the action that might be taken by any of the others, did not require as a condition of its acceptance that Masonite make such an agreement with any of the others, and had no discussions with any of the others. It is not clear at what precise point of time each appellee became aware of the fact that its contract was not an isolated transaction but part of a larger arrangement. But it is clear that as the arrangement continued each became familiar with its purpose and scope. Here as in Interstate Circuit, Inc, v. United States, . . . It was enough that, knowing that concerted action was contemplated and invited, the distributors gave their adherence to the scheme and participated in it." "United States v. Afasonite Corp., 316 U.S. 265, 27475 (1942). See also United States v. Paramount Pictures, Inc, 334 U.S. 131, 142 (1948) ; United States v. Bausch \& Lomb Optical Co., 321 U.S. 707, 723 (1944); United States v. United States Gypsum Co., 333 U.S. 364, 393-94 (1948); Interstate Circuit, Inc. v. United States, 305 U.S. 208, 226-27 (1939).

39. United States v. Paramount Picture's, Inc., 334 U.S. 131, 161 (1948). Cf. United States v. Bausch \& Lomb Optical Co., 321 U.S. 707, 723 (1944).

40. Economic coercion is no defense in criminal law. See Hald, General Paincipals of Crimmal Law 411-15 (1947); Mrrler, Crumisat. Law 164-66 (1934). Nor is it a defense in antitrust litigation. Interstate Circuit, Inc v. United States, 306 U.S. 208, 230 (1939). In United States v. Line Material Co., 333 U.S. 287, 297 (1948), the Supreme Court, in finding a conspiracy, stated that all the manufacturers were forced to accept the terms of the licensor or cease manufacture although several of the licenseus were opposed to the price limitations imposed on them. See also United States v. Waltham Watch Co., 47 F. Supp. 524, 533 (S.D.N.Y. 1942) ; Note, 54 CoLvar. L. REx. 1103, 1123 (1954).

41. Although "pari delicto" is sometimes a good defense, it is barred where plaintiff proves economic coercion or duress. Eastman Kodak Co. v. Southern Photo Materials Co., 273 U.S. 359 (1927); Ring v. Spina, 148 F.2d 647 (2d Cir. 1945); Allgair v. Glenmore Distilleries Co., 91 F. Supp. 93 (S.D.N.Y. 1950). In Ring v. Spina, supro, the Second Circuit stated that victims and those actively engaged in promoting the monopoly should be distinguished. However, it then suggested that even proof of econonie coercion may not be necessary for dealers in positions analogous to Nelson and Mfeyberg. Ring v. Spina, supra, at 653. Cf. Note, 38 Mins. L. Rev. 883 (1954). Buf cf. Pennsylvania Water \& P. Co. v. Consolidated G.E.L. \& P. Co., 209 F.2d 131 (Ath Cir. 1953). "Pari delicto" will also be an unsuccessful defense when the plaintiff's cause of action arises after he leaves the illegal scheme. See, i.g., Connecticut Importing Co. v. Frankfort Distilleries, Inc, 101 F.2d 79 (2d Cir. 1939). Of course, damages will only be measured from the time the plaintiff leaves the combination. For the history of the "pari delicto" defense, see Lockhart, Violation of the Anti-trust Laws as a Defense in ("zill Actions, 31 IINN. L. REv. 507 (1947). 
In Nelson $v$. Motorola, ${ }^{42}$ plaintiff charged a conspiracy in violation of Section 1 of the Sherman Act as well as a violation of the Clayton Act. Nelson alleged that the officers of Motorola had conspired among themselves and with the corporate entity to restrain trade in Motorola communication equipment. The court found that the acts of the officers were acts of the corporation and rejected plaintiff's theory that a corporation can conspire with itself. It held that two persons or entities were necessary to have a conspiracy and dismissed the charge because only one entity was involved in plaintiff's allegations. ${ }^{43}$ However, the court stated that if Motorola's operations were carried on by parent and subsidiary corporations, those separate corporate entitics could be found guilty of a conspiracy in restraint of trade. ${ }^{44}$ Since the nationwide conspiracy charge which Interstate suggests would be brought against the manufacturer and his exclusive dealers, $N$ elson supports the theory that the Sherman Act can be used effectively against many refusal-to-deal situations.

Employment of the Interstate formula also eliminates another defect in the Nelson complaint. The Nelson court stated that contracts with other distributors did not injure plaintiff.45 But if a nation-wide conspiracy were charged, the injury to plaintiff would be clear. For then those contracts would be viewed as part of an overall scheme by which plaintiff is restricted from the possibility of increased income through the sale of competing goods. ${ }^{40}$

After a conspiracy is established, the unreasonableness of the restriction on competition must be shown to prove a violation of the Sherman Act. ${ }^{47}$ And in a private suit the plaintiff must also demonstrate that he has been injured

42. 200 F.2d 911 (5th Cir. 1952), cert. denied, 345 U.S. 925 (1953).

43. Nelson Radio \& Supply Co., Inc. v. Motorola, Inc., 200 F.2d 911,914 (5th Cir. 1952). See Marion County Co-op Ass'n v. Carnation Co., 114 F. Supp. 58 (W.D. Ark. 1953). But cf. White Bear Theater Corp. v. State Theater Corp., 129 F.2d 600 (8th Cir. 1942); Patterson v. United States, 222 Fed. 599 (6th Cir. 1915). For a persuasive argument that the court should have found an intracorporate conspiracy in Nelson, sce Comment, 63 Y ALE I.J. 372, 385-87 (1954).

44. Nelson Radio \& Supply Co. v. Motorola, Inc., 200 F.2d 911, 914 (5th Cir. 1952) (dictum).

45. Id. at 915

46. See Lockhart \& Sacks, The Relevance of Economic Factors in Detcrminimy Whether Exclusive Arrangements Violate Section 3 of the Clayton Act, 65 HAwv. L. Rws. 913, 922 (1952). Cf. Bigelow v. RKO Radio Pictures, 327 U.S. 251 (1946); Frey \& Son v. Welch Grape Juice Co., 240 Fed. 114 (4th Cir. 1917).

47. Hudson Sales Corp. v. Waldrip, 211 F.2d 268 (5th Cir. 1954); Feddersen Motors, Inc. v. Ward, 180 F.2d 519 (10th Cir. 1950); Whitwell v. Continental Tobacco Co., 125 Fed. 454 (8th Cir. 1903); United States v. J. I. Case Co., 101 1. Supp. 856 (D. Mimm. 1951). See Kahn, A Legal and Economic Appraisal of the "New" Sherman and Clayton Acts, 63 YaLe L.J. 293, 313-37 (1954). See also Standard Oil Co. of New Jersey v. United States, 221 U.S. 1 (1911); Board of Trade v. United States, 246 U.S. 231 (1918); Appalachian Coals, Inc. v. United States, 288 U.S. 344 (1933). The "rule of reason" requires consideration of all the factors and circumstances in any given situation. However, if the conspiracy is considered a group boycott, see text at note 36 supra, the burden on plaintiff may not be sc great. See Justice Reed's dictum in United States v. Columbia Steel Co., 334 U.S. 495, 522 (1948) (concerted refusals to deal are illegal per se); 
by the acts constituting the violation. ${ }^{48}$ Due to Standard Stalions, ${ }^{\text {t0 }}$ the plaintiff has a lighter burden in proving the probability of a substantial lessening of competition under the Clayton $A c t{ }^{50}$ rather than an unreasonable restraint of trade under the Sherman Act. ${ }^{51}$ Nevertheless, the allegation of a conspiracy in violation of the Sherman Act has the advantage of avoiding the application of the Colgate doctrine and of making the courts face the real issue involved, the effect of the distribution method on competition. ${ }^{52}$

Kirkpatrick, Commercial Boycotts as Per Se Fiolations of the Sherman Ate, 10 Geo. WASH. L. Rev. 302, 387 (1942); Oppenheim, Federal Antitrust Legislation: Gutideposts to a Revised National Antitrust Policy, 50 Mfrce. L. Rev. 1136-10, 1150-51 (1952). But see Comment, 58 YALE L.J. 1121, 1138 (1949).

48. Twin Ports Oil Co. v. Pure Oil Co., 119 F.2d 747 (Sth Cir. 1941). Private suits are authorized by $\S 4$ of the Clayton Act. 38 STAT. 731 (1914), 15 U.S.C. $\$ 15$ (1952).

49. Standard Oil Co. of California v. United States, 337 U.S. 293 (1949).

50. See notes 9,10 , supra.

51. Standard Oil Co. of California v. United States, 337 U.S. 293, 311-14 (1949); Times Picayune v. United States, 345 U.S. 594, 609-11 (1953). See note 47 supra. See also Schwartz, Potential Impairment of Competition-The Impact of Standard Oil of California $\approx$ United States on the Standard of Legality Under the Clayton Act, 98 U. PA. L. REY. 10 (1949).

52. "So far as the Sherman Act is concerned the result must turn not on the skill with which counsel has manipulated the concepts of 'sale' and 'agency' but on the significance of the business practices in terms of restraint of trade" United States v. Mrasonite Corp., 316 U.S. 265, 280 (1942). See note 26 stpra. See also Comment, Intra-Ensterprise Conspiracy Under the Sherman Act, 63 YALE L.J. 372, 388 (1954); Rahl, Conspiracy and the Anti-Trust Laws, 44 ILr L. Rer. 743, 76 S (1950). 